\title{
Determination of sports health belief levels of individuals who do sports for recreational purposes
}

\author{
Mustafa VURAL, Yasar CORUH \\ School of Physical Education and Sports, A ̆grı İbrahim Çeçen University, A $\breve{g} r$, Turkey. \\ Address correspondence to M. Vural, e-mail: mustafaavurall@gmail.com
}

\begin{abstract}
This study was carried out in order to determine sports health belief levels of individuals participating in sporting recreational activities in sports facilities belonging to Konya Metropolitan Municipality in terms of some demographic variables. A method for descriptive survey aimed at revealing the current situation was used in the research. Sample group of the study consists of 150 participants (female $=66 /$ male $=84$ ) who attend the courses opened in Konya Metropolitan Municipality. In the study, "Sport Health Belief Scale" with 5 sub-dimensions developed by Ertüzün and personal information form developed by the researcher were used. In the analysis of the data, "Kolmogorov-Smirnov" test was performed for normality test and it was determined that data had normal distribution. While comparing data according to normality test in terms of female and male, independent samples T test was used. One-way Anova test was used in multiple comparisons in terms of sport year and age and Tukey test was applied in order to determine difference between the groups because of variance homogeneity. Significance level in the study was determined as $=0.05$. As a result of the research, when comparisons were examined according to gender variables, there was a significant difference between male and female athletes in terms of perceived seriousness, perceived obstacles, physical benefits and psychological benefits sub-dimensions which are sports health belief scale sub-dimensions, but differences were not determined in self-efficacy sub-dimension. A significant difference was determined in educational status variable. It was determined that perceived seriousness, physical benefits, psychological benefits and perceived obstacles levels of individuals aged 17-20 years were significantly different from individuals aged 26-30 and +30. In sport year variables, it was concluded that perceived seriousness dimension of individuals whose exercise period was between 3 months- 1 year was significantly different from those whose exercise period was +2 years and self-efficacy perceptions of individuals who hadn't done sports were significantly different from those whose exercise period was 3 months- 1 year and +2 years.
\end{abstract}

Keywords: Health, recreation, sport.

\section{INTRODUCTION}

When it is looked at past periods, it is seen that the only purpose of people is to survive and to continue their lives. This situation has become important in today's people. So, it shouldn't be forgotten that sports coincide with leisure times (9). People have become more active each passing day with possibilities and opportunities brought by development. As a result, industrialization and mechanization formed immobile employment opportunities and working environments together (1). An increase in leisure time was observed as a result of industrialization's effect and importance of recreation increased considerably. Recreation means recreational and entertaining activities voluntarily performed by people or communities in their leisure times (9).
People can purify and renew their bodies, souls and thoughts through these activities by experiencing feelings such as relaxation, renewal, change, escaping from daily problems (2). Health concept includes life satisfaction and quality of life and all dimensions of life such as physical well-being, social interactions, mental and emotional capacities and spiritual situations. When person and environment integrity are considered, it is seen that health which is considered as a developmental phenomenon affects consciousness, personal experience, and selfrealization (4). Accordingly, the concepts of recreation and health interact in many ways. Today, people have to move insufficiently during their lifetime and this has led to emergence of a new disease group. This disease has manifested itself as Hypo kinetic disease (15). Accordingly, activity is indispensable for people. It is necessary to rest 
spiritually in order to be healthy. Because spiritual tension hurts and damages one's social relations (12).

Beliefs represent constant emotions that are formed by individuals' perceptions and definitions about one aspect of their own world. When individuals want to reveal their knowledge, opinions and beliefs, they show their behavior and attitudes prominently (5). Human health is considerably related to attitudes and beliefs. Along with this, theorists have developed health behavior models (5). In recent years, health belief model is the most frequently used model for describing health behaviors. The basic concept of the model is to explain the determinants about implementation of preventive health behaviors (7). At the same time, model describes what motivates the person to perform or not to perform health-related actions and situations that affect especially displaying health behaviors (11). The idea of the fact that sports protect health outside of competition began to gain importance and masses of people were invited to sports events. Number of people engaged in sports has been tried to be increased in order to protect health with physical activities and various slogans such as sports for healthy life, life-long sports, and sports for everyone, fitness, aerobics (8). For this reason, it has been seen that recreational exercises and sports as preventive health services increased day by day and found value among people and also increased day by day (6). Therefore, in this study, it was aimed to determine levels of sports health beliefs of individuals who do recreational sports.

\section{MATERIALS \& METHODS}

\section{Model of the research}

A method for descriptive survey aimed at revealing the current situation was used in the research.

\section{Universe and Sampling}

Universe of the research consists of individuals participating in sporting recreational activities in sports facilities belonging to Konya Metropolitan Municipality. All the individuals were tried to be reached by applying surveys but the research was limited to the individuals who voluntarily participated in the survey. It this way, 150 individuals (Female=66 / Male=84) participated in this study.

\section{Data Collection Tools}

In the research, "Sport Health Belief Scale" with 5 sub-dimensions developed by Ertüzün (6) and personal information form with 5 articles developed by the researcher were used.

\section{Sports Health Belief Scale}

The survey developed by Ertüzün (6) was first applied to 400 people and then, applied to 323 people again from the study group and relationship between measurements the two practices was calculated by using Pearson product-moment correlation coefficient and t-test was used for differential relationship sample. For reliability analysis, Cronbach alpha internal consistency coefficient was calculated as 0.88 . Reliability results according to subdimensions were calculated as follows; perceived seriousness $=.82$, perceived obstacles $=.50$, physical benefit $=.82$, psychosocial benefit $=.87$, self-efficacy $=$ $.76(6)$.

\section{Data Analysis}

SPSS 15.0 statistical package program was used to evaluate data and find calculated values. "Kolmogorov-Smirnov" test was performed for data normality test and it was determined that data had normal distribution. While comparing data according to normality test in terms of female and male, independent samples $\mathrm{T}$ test was used. One-way Anova test was used in multiple comparisons in terms of sport year and age and Tukey test was made in order to determine difference between the groups because of variance homogeneity. Data were presented as mean and standard deviation. Error level in this study was taken as 0.05 .

\section{RESULTS}

When Table 1 was examined, it was seen that in comparison of sports health belief scale subdimensions in terms of males and females, there were significant difference between averages of males and females in terms of perceived seriousness, perceived obstacles, physical benefits and psychological benefits sub-dimensions $\quad(\mathrm{P}<0.05)$. Significant differences were not determined between averages of males and females in terms of self-efficacy subdimension.

When Table 2 was examined, it was seen that in comparison of sports health belief scale subdimensions in terms of educational status, there were significant difference between averages of males and females in terms of perceived seriousness and perceived obstacles sub-dimensions $(\mathrm{P}<0,05)$. On the other hand, significant differences were not determined between averages of males and females 
in terms of physical benefits, psychological benefits and self-efficacy sub-dimension.

When Table 3 was examined, it was determined that in multiple comparison of sports health belief scale sub-dimensions in terms of age, individuals between the age of 17-20 are significantly different from individuals between the age of 26-30 and +30 in terms of perceived seriousness and perceived obstacles sub-dimensions, individuals between the age of 17-20 are significantly different from individuals between the age of 21-25, 26-30 and +30 in terms of physical benefits, individuals between the age of 17-20 are significantly different from individuals between the age of +30 in terms of psychological benefits $(\mathrm{P}<0.05)$. Significant differences were not determined between any age group in terms of self-efficacy sub-dimension.

Table 1. Comparison of sports health belief scale sub-dimensions of men and women participating in the research in terms of gender.

\begin{tabular}{llllclcc}
\hline Sub-dimensions & Gender & $\mathrm{N}$ & Mean & Difference of Means & $\mathrm{SD}$ & $\mathrm{t}$ & $\mathrm{p}$ \\
\hline Perceived Seriousness & Male & 84 & 14.08 & 1.01 & 2.24 & 2.265 & $.025^{*}$ \\
& Female & 66 & 13.07 & & 3.21 & & \\
Perceived Obstacles & Male & 84 & 8.10 & 1.01 & 2.23 & 2.537 & $.012^{*}$ \\
& Female & 66 & 7.08 & & 2.66 & & \\
Physical Benefit & Male & 84 & 14.08 & 1.85 & 2.00 & 4.236 & $.000^{*}$ \\
& Female & 66 & 12.23 & & 3.31 & & \\
Psychological Benefit & Male & 84 & 20.24 & 1.33 & 3.22 & 2.025 & $.045^{*}$ \\
& Female & 66 & 18.91 & & 4.80 & & \\
Self-Efficacy & Male & 84 & 10.11 & -0.47 & 3.65 & -.774 & .440 \\
& Female & 66 & 10.58 & & 3.67 & & \\
\hline
\end{tabular}

Table 2. Comparison of sports health belief scale sub-dimensions of men and women participating in the research in terms of educational levels.

\begin{tabular}{|c|c|c|c|c|c|c|c|}
\hline Sub-dimensions & Educational Status & $\mathrm{N}$ & Mean & Difference of Means & SD & $\mathrm{t}$ & $\mathrm{p}$ \\
\hline \multirow[t]{2}{*}{ Perceived Seriousness } & High School & 69 & 13.12 & -.94 & 3.04 & -2.124 & $.035^{*}$ \\
\hline & University & 81 & 14.07 & & 2.40 & & \\
\hline \multirow[t]{2}{*}{ Perceived Obstacles } & High School & 69 & 7.03 & -1.15 & 2.44 & -2.901 & $.004^{*}$ \\
\hline & University & 81 & 8.18 & & 2.40 & & \\
\hline \multirow[t]{2}{*}{ Physical Benefit } & High School & 69 & 12.89 & -.70 & 3.26 & -1.522 & .130 \\
\hline & University & 81 & 13.58 & & 2.32 & & \\
\hline \multirow[t]{2}{*}{ Psychological Benefit } & High School & 69 & 19.48 & -.32 & 4.32 & -.483 & .630 \\
\hline & University & 81 & 19.80 & & 3.78 & & \\
\hline \multirow[t]{2}{*}{ Self-Efficacy } & High School & 69 & 10.58 & .50 & 3.58 & .829 & .408 \\
\hline & University & 81 & 10.09 & & 3.72 & & \\
\hline
\end{tabular}


Table 3. Multiple comparison of sports health belief scale sub-dimensions in terms of age.

\begin{tabular}{lccccc}
\hline Sub-dimensions & Sum of Squares & Mean of Squares & $\mathrm{F}$ & $\mathrm{p}$ & Difference \\
\hline Perceived Seriousness & 65.99 & 22.00 & 3.036 & $0.031^{*}$ & A-C and D \\
Perceived Obstacles & 102.33 & 34.11 & 6.146 & $0.001^{*}$ & A-C and D \\
Physical Benefit & 119.09 & 39.70 & 5.515 & $0.001^{*}$ & A-B,C and D \\
Psychological Benefit & 147.30 & 49.10 & 3.156 & $0.027^{*}$ & A-D \\
Self-Efficacy & 16.89 & 5.63 & .417 & 0.741 & N/A \\
\hline
\end{tabular}

A: 17-20; B: 21-25; C: 26-30; D: +30

Table 4. Multiple comparison of sports health belief scale sub-dimensions in terms of sport year.

\begin{tabular}{lccccc}
\hline Sub-dimensions & Sum of Squares & Mean of Squares & $\mathrm{F}$ & $\mathrm{p}$ & Difference \\
\hline Perceived Seriousness & 55.25 & 27.63 & 3.801 & $.025^{*}$ & A-B \\
Perceived Obstacles & 12.49 & 6.24 & 1.019 & .363 & N/A \\
Physical Benefit & 20.42 & 10.21 & 1.305 & .274 & N/A \\
Psychological Benefit & 2.78 & 1.39 & .085 & .919 & N/A \\
Self-Efficacy & 279.27 & 139.64 & 12.002 & $.000^{*}$ & C-A and B \\
\hline
\end{tabular}

A: 3 months - 1year; B: +2 ; C: None

When Table 4. was examined, it was seen that in multiple comparison of sports health belief scale subdimensions in terms of sport year, perceived seriousness dimension of individuals whose exercise period was between 3 months-1 year was significantly different from those whose exercise period was +2 years and self-efficacy perceptions of individuals who hadn't done sports were significantly different from those whose exercise period was 3 months -1 year and +2 years $(\mathrm{P}<0.05)$. Differences were not determined between any sport year group in terms of other sub-dimensions.

\section{DISCUSSION}

In this research that was conducted in order to determine levels of sports health beliefs of individuals who do recreational sports in gyms in terms of different demographic variables, following results were obtained.

When comparison of sports health belief scale sub-dimensions of individuals participating in the research was examined in terms of gender, it was concluded that perceived seriousness, perceived obstacles, physical benefits and psychological benefits sub-dimensions differentiated significantly on behalf of males, self-efficacy sub-dimension did not differ for male and female participants. In a gender-based study, it was determined that "Psychosocial Benefits" and "Self-Efficacy" sub- dimensions cause significant differences between male and female participants (14). In general terms, when we consider the fact that men need to show themselves as external appearance in society, to feel good physically and psychologically, we can say that they take activities done more seriously.

When results of the research were analyzed according to age, it was determined that seriousness, physical benefits, psychological benefits, and perceived obstacles sub-dimensions' levels increased as age increased. In other words, situation is in parallel with age. This shows that individuals who are younger are less affected by situations such as seriousness, physical benefits, psychological benefits and perceived obstacles which are sports health belief sub-dimensions than those who are older in age. In other words, it can be said that as age increases, individuals abstain from some situations (health complaints, thinking about disablement, loss of strength, flexibility, etc.) and become distanced.

When sport year was examined, it was determined that perceived seriousness level of individuals who just started to do sports was significantly higher than individuals who had been doing sports for a long time. It is possible to say that individuals who are new in doing sports are enthusiastic, their desire to participate in activities and to be there is very high and they are serious about what they want to do. Self-efficacy levels of the 
individuals who never do sports have been found to be higher than those who have been doing sports for a long time. When it is considered that self-efficacysufficiency is "Perception or attitude of an individual to perform a certain action successfully or to control events" (10)" or attitude of an individual about capacity of an individual to achieve a certain level of performance (3), attitude of an individual (13), it is possible to say that individuals who never do sports are prejudiced, in other words, they have a high opinion of whether they can or cannot do an action in advance. It has been seen that individuals have a high degree of seriousness and perception in terms of health belief in recreational activities.

\section{REFERENCES}

1. Akgün N. Egzersiz fizyolojisi. 2. Baskı. İzmir: Ege Üniversitesi Basımevi, 1980.

2. Bammel G, Burrus-Bammel LL. Leisure \& human behavior. 3rd edition. USA, Madison: Brown \& Banchmark Publishers, 1996.

3. Bandura A. Self-efficacy mechanism in human agency. American Psychologist, 1982; 37(2): 122-147.

4. Edelman C, Mandle CL. Health promotion throughout the lifespan. 4th ed. St. Luis: C.V. Mosby, 1998.

5. Eren E. Örgütsel Davranış ve Yönetim Psikolojisi. Genişletilmiş 6. Baskı. İstanbul: Beta Basım Yayın Dağıtım, 2000.
6. Ertüzün E. Kadınların Sportif Rekreasyonel Aktivitelere İlişkin Sağlık İnançları. Doktora tezi. Gazi üniversitesi, Sağlık Bilimleri Enstitüsü, Ankara, 2013.

7. Glanz K, Rimer BK. Lewis FM. Health Behavior and Health Education. Theory, Research and Practice. San Fransisco: Wilwy \& Sons, 2002.

8. Kalyon TA. Spor Hekimliği. 5. Baskı. Ankara: Gata Yayınları, 2000.

9. Karaküçük S. Rekreasyon, boş zamanları değerlendirme. Ankara: Gazi kitabevi, 2005.

10. Magil FN. (Eds) Survey of social science, Psychology series. Englewood Cliff: Salem press. N. J. Iltrochim corneiiedulganery/walkley/self-eff. Htm. 1993.

11. Mikhail BI. The Health Belief Model; A review and critical evaluation of the model, research and Practice. Advances in Nursing Science Series, 1981; 4: 65-81.

12. Özden M. Sağlık Eğitimi. 1. Baskı. Ankara: Feryal Matbaacılık, 1993.

13. Senemoğlu N. Gelişim Öğrenme ve Öğretim: Kuramdan Uygulamaya. Ankara: Özsen Matbaası, 1998.

14. Yalcin B, Arslan F. Health beliefs of university students with regard to sportive recreational activities: The case of Batman and Gümüşhane Universities. Int Journal of Health Manag and Tourism 2016; 1(1): 2-13.

15. Zorba E. Sporla Aktif Yaşam ve Sağlığımız Kazandırdıkları: Yaşam ve Egzersiz. Gazi Haber Dergisi, 2007: 44-47. 